\title{
Nutrient Scheduling for Baby Corn (Zea mays L.) Intercropped in Coconut Garden
}

\author{
Vinod Mavarkar ${ }^{1}$, P. Shalini Pillai ${ }^{1 *}$ and N.V. Radhakrishnan ${ }^{2}$ \\ ${ }^{1}$ Department of Agronomy, Kerala Agricultural University, College of Agriculture, \\ Vellayani, Thiruvananthapuram, Kerala, India \\ ${ }^{2}$ Kerala Agricultural University, Coconut Research Station, Balaramapuram, \\ Thiruvananthapuram, Kerala, India
}

*Corresponding author

\begin{abstract}
A B S T R A C T
Keywords

Baby corn,

Economic, Growth,

Nutrients, Yield

Article Info

Accepted:

15 August 2019

Available Online:

10 September 2019

A field experiment was conducted at the Coconut Research Station, Balaramapuram, Thiruvananthapuram, during the summer season to work out an economic nutrient management schedule for baby corn intercropped in coconut garden. The experiment was laid out in randomized block design with 10 treatments replicated thrice, using the baby corn hybrid, G 5414 as a test variety. Plant height $(125.16 \mathrm{~cm})$ at 30 days after emergence (DAE), number of leaves per plant at $45 \mathrm{DAE}$ (11.87), leaf area index at $15 \mathrm{DAE}(0.365)$, $30 \mathrm{DAE}$ (2.25) and $45 \mathrm{DAE}$ (4.28) and dry matter production (24203.70 kg ha ${ }^{-1}$ ) were significantly superior at $\mathrm{T}_{7}$ The yield attributes viz., cob length $(11.60 \mathrm{~cm})$, cob girth $(5.30$ $\mathrm{cm})$ and cob weight with husk (84.22 $\left.\mathrm{g} \mathrm{plant}^{-1}\right)$ recorded significantly higher values at $\mathrm{T}_{7}$. Similar results were also recorded with respect to cob yield with husk $\left(17162.66 \mathrm{~kg} \mathrm{ha}^{-1}\right)$, marketable cob yield $\left(6720.67 \mathrm{~kg} \mathrm{ha}^{-1}\right)$ and green stover yield $\left(26203.70 \mathrm{~kg} \mathrm{ha}^{-1}\right)$. All the above yield attributes (except cob weight with husk) were on a par with $\mathrm{T}_{4}$. The uptake of nitrogen (304.64 kg ha-1), phosphorus $\left(59.65 \mathrm{~kg} \mathrm{ha}^{-1}\right)$ and potassium $\left(277.01 \mathrm{~kg} \mathrm{ha}^{-1}\right)$ was significantly higher with the treatment $\mathrm{T}_{7}$. Gross income ( $\left(2,68,827 \mathrm{ha}^{-1}\right)$, net income (₹ 1,90,367 $\mathrm{ha}^{-1}$ ) and benefit cost ratio (3.43) were significantly higher in $\mathrm{T}_{7}$. Baby corn intercropped in coconut garden was observed to be superior with the application of FYM @ 12.5 $\mathrm{t} \mathrm{ha}^{-1}+135: 65: 45 \mathrm{~kg} \mathrm{NPK} \mathrm{ha}^{-1}(1 / 2 \mathrm{~N}+$ full $\mathrm{P}+\mathrm{K}$ as basal; $1 / 2 \mathrm{~N}+1 / 2 \mathrm{~K} @ 25$ DAS).
\end{abstract}

\section{Introduction}

Maize, referred to as the 'king of cereals' is a good grain crop with high yield potential, superior fodder quality and dual purpose value as comparable to other food crops. Baby corn is one such dual purpose maize, whose global spread, increasing demand and premium price has made it an attractive option for the farmers in many countries including India. It has the potential of producing high biomass within a short period of time and can also serve as a source of fresh fodder, especially during the summer months. Baby corn because of its 
fodder value and more profitability than grain maize is helpful in raising the income of the farmers near metros and big cities (Pandey et al., 2000). It is so called because young, fresh and finger like green ears are harvested before or just at the time of silk emergence and before fertilization, which upon dehusking and desilking is used as vegetable. Baby corn ears are light yellow colour with regular row arrangement, 10 to $12 \mathrm{~cm}$ long and a diameter of 1.0 to $1.5 \mathrm{~cm}$ sizes are preferred in the market (Muthukumar et al., 2005). Further, it is a low calorie, zero cholesterol food with high fibre content (Nagdeve et al., 2014). The land and climate of Kerala is suitable for a number of crops. About 45 per cent of the net area sown is under perennial crops like coconut. Studies conducted in Tamil Nadu and isolated pockets in Kerala, have shown that baby corn production could be an important on-farm income generation activity when intercropped with annual crops (Thavaprakash and Velayudham, 2008) and perennial crops like coconut (CPCRI, 2012). Baby corn is comparatively a new crop for Kerala and small farmers are often hesitant in trying new crops under sole cropping situations, since it involves certain degree of risk. Coconut gardens provide ample scope for intercropping. Baby corn production being a very recent development, cultivation practices, especially nutrient management needs to be standardized before it finds a prominent place in the existing cropping systems with the following objectives to standardize the nutrient schedule for baby corn intercropped in coconut garden and to work out the economics.

\section{Materials and Methods}

A field experiment was conducted at the Coconut Research Station, Balaramapuram, Thiruvananthapuram, during the summer season (March to May), 2017. The soil of experimental field was sandy loam in texture, acidic in reaction ( $\mathrm{pH} 4.60)$, low in available nitrogen $(200.70 \mathrm{~kg} \mathrm{~N} / \mathrm{ha})$, medium in available phosphorus (18.56 kg P/ha) and available potassium (108.70 kg K/ha). The experiment was laid out in randomised block design with 10 treatments replicated thrice, using the baby corn hybrid, G 5414 as the test variety. The treatments comprised combinations of 3 nutrient doses, 3 split application schedules and a control. The treatments were $\mathrm{T}_{1}: 100: 40: 60 \mathrm{~kg}$ NPK ha ${ }^{-1}$ $(1 / 2 \mathrm{~N}+1 / 2 \mathrm{~K}$ basal; $1 / 2 \mathrm{~N}+1 / 2 \mathrm{~K}$ at $25 \mathrm{DAS}) ; \mathrm{T}_{2}$ : 100:40:60 kg NPK ha ${ }^{-1}(1 / 2 \mathrm{~N}+1 / 2 \mathrm{~K}$ basal; $1 / 2$ $\mathrm{N}+1 / 2 \mathrm{~K}$ at $45 \mathrm{DAS}) ; \mathrm{T}_{3}: 100: 40: 60 \mathrm{~kg} \mathrm{NPK}$ ha $^{-1}(1 / 2 \mathrm{~N}+1 / 2 \mathrm{~K}$ basal; $1 / 4 \mathrm{~N}+1 / 4 \mathrm{~K}$ at 25 DAS; $1 / 4 \mathrm{~N}+1 / 4 \mathrm{~K}$ at $45 \mathrm{DAS}) ; \mathrm{T}_{4}: 150: 60: 40$ $\mathrm{kg}$ NPK ha ${ }^{-1}(1 / 2 \mathrm{~N}+1 / 2 \mathrm{~K}$ basal; $1 / 2 \mathrm{~N}+1 / 2 \mathrm{~K}$ at 25 DAS); $\mathrm{T}_{5}: 150: 60: 40 \mathrm{~kg} \mathrm{NPK} \mathrm{ha}{ }^{-1}(1 / 2 \mathrm{~N}+$ $1 / 2 \mathrm{~K}$ basal; $1 / 2 \mathrm{~N}+1 / 2 \mathrm{~K}$ at $45 \mathrm{DAS}) ; \mathrm{T}_{6}$ : 150:60:40 kg NPK ha ${ }^{-1}(1 / 2 \mathrm{~N}+1 / 2 \mathrm{~K}$ basal; $1 / 4$ $\mathrm{N}+1 / 4 \mathrm{~K}$ at $25 \mathrm{DAS} ; 1 / 4 \mathrm{~N}+1 / 4 \mathrm{~K}$ at $45 \mathrm{DAS})$; $\mathrm{T}_{7}: 135: 65: 45 \mathrm{~kg}$ NPK ha ${ }^{-1}(1 / 2 \mathrm{~N}+1 / 2 \mathrm{~K}$ basal; $1 / 2 \mathrm{~N}+1 / 2 \mathrm{~K}$ at $25 \mathrm{DAS}) ; \mathrm{T}_{8}: 135: 65: 45$ $\mathrm{kg}$ NPK ha ${ }^{-1}(1 / 2 \mathrm{~N}+1 / 2 \mathrm{~K}$ basal; $1 / 2 \mathrm{~N}+1 / 2 \mathrm{~K}$ at $45 \mathrm{DAS}) ; \mathrm{T}_{9}: 135: 65: 45 \mathrm{~kg} \mathrm{NPK} \mathrm{ha}{ }^{-1}(1 / 2 \mathrm{~N}+$ $1 / 2 \mathrm{~K}$ basal; $1 / 4 \mathrm{~N}+1 / 4 \mathrm{~K}$ at 25 DAS; $1 / 4 \mathrm{~N}+1 / 4$ $\mathrm{K}$ at 45 DAS) and $\mathrm{T}_{10}$ : control. Farm yard manure @12.5 t ha ${ }^{-1}$ was applied uniformly to all the treatments, including control. The entire dose of phosphorus was applied basally to the treatments $\mathrm{T}_{1}$ to $\mathrm{T}_{9}$.

Biometric observations were recorded from six plants selected at random in the net plot. Plant height was measured from base to tip of the terminal leaf on the main stem and expressed in $\mathrm{cm}$. The number of functional leaves per plant was recorded by counting the fully opened green leaves. Leaf area index was measured by using the formula given by (Balakrishnan et al., 1987). The uprooted plants were dried under shade and then oven dried at $60+5{ }^{0} \mathrm{C}$ till a constant weight was obtained and expressed in $\mathrm{kg} \mathrm{ha}^{-1}$. Weight of cobs with husk from the tagged plants was measured. Sheath of cobs was peeled-off and 
the length and diameter of corn were measured. The weight of the unhusked cobs was recorded and expressed in $\mathrm{kg} \mathrm{ha}^{-1}$. The cobs from the sample plants were dehusked and weight of the corn was recorded and the total marketable cob yield was expressed in $\mathrm{kg}$ $\mathrm{ha}^{-1}$. After the final harvest of the cobs, the plants of each net plot was cut close to the ground, weighed and weight was expressed in $\mathrm{kg} \mathrm{ha}^{-1}$. Nitrogen, phosphorus and potassium in plants were estimated by the standard methods advocated by Jackson (1973).

Gross income was calculated by multiplying the marketable cob yield with the market price of the produce and expressed as gross income in $₹ \mathrm{ha}^{-1}$. The net returns was calculated by deducting the cost of cultivation from the gross returns and expressed in $₹ \mathrm{ha}^{-1}$. Ratio of net return to cultivation cost was the benefit cost ratio. The data generated from the experiment were statistically analyzed using Analysis of Variance technique (ANOVA) as applied to Randomised Block Design (Panse and Sukhatme, 1985).

\section{Results and Discussion}

\section{Growth and growth attributes}

Plant height of baby corn was observed to vary significantly among the different nutrient schedules, at 30 days after emergence (DAE). The plants were significantly taller in $\mathrm{T}_{7}(135$ : 65: $45 \mathrm{~kg} \mathrm{NPK} \mathrm{ha}^{-1} ; 1 / 2 \mathrm{~N}+1 / 2 \mathrm{k}$ as basal; $1 / 2 \mathrm{~N}$ $+1 / 2 \mathrm{~K}$ at $25 \mathrm{DAS}$ ), which was on par with $\mathrm{T}_{4}$ (150: 60: $40 \mathrm{~kg} \mathrm{NPK} \mathrm{ha}{ }^{-1} ; 1 / 2 \mathrm{~N}+1 / 2 \mathrm{k}$ as basal; $1 / 2 \mathrm{~N}+1 / 2 \mathrm{~K}$ at 25 DAS).

The effect of nutrient schedules was significant with respect to the number of leaves per plant at $45 \mathrm{DAE}$. Leaf number was significantly higher (11.89) in $\mathrm{T}_{7}$. It remained at par with all the other treatments, expect $\mathrm{T}_{8}$ and $\mathrm{T}_{10}$ (control). Significantly higher leaf area index was recorded with the treatment $\mathrm{T}_{7}$ at 15 DAE (0.365), 30 DAE (2.254) and 45
DAE (4.286). Balanced nutrition might have supported rapid cell division and elongation of cells, there by contributing to improved growth attributes of baby corn. Similar results have been observed by Sobhana et al. (2012) and Kumar and Bohra (2014).

The treatment $\mathrm{T}_{7}\left(24203.70 \mathrm{~kg} \mathrm{ha}^{-1}\right)$ proved significantly superior in terms of the total dry matter produced by baby corn. Dry matter production is a function of plant height, number of leaves, leaf area index and yield. Among the three major nutrients, nitrogen plays an important role in plant growth, since it is an integral constituent of cell component (Mohan et al., 2015).

Further Muchow and Davis (1988) have reported that nitrogen fertilization of maize influenced the dry matter yield by influencing the leaf area index and photosynthetic efficiency. Potassium application improves leaf area, dry matter accumulation and other allometric parameters. $\mathrm{K}$ in combination with $\mathrm{N}$ has synergistic influence in uptake, translocation and utilization of nutrients for assimilation in growth and development and yield and its contributing attributes (Ahmad et al., 2012) (Table 1).

\section{Yield attributes and yield}

The yield attributes viz., cob length (11.60 $\mathrm{cm})$, cob girth $(5.30 \mathrm{~cm})$ were significantly higher with treatment $T_{7}$ (135:65:45 kg NPK ha $^{-1} 1 / 2 \mathrm{~N}+1 / 2 \mathrm{~K}$ basal; $1 / 2 \mathrm{~N}+1 / 2 \mathrm{~K}$ at $\left.25 \mathrm{DAS}\right)$ which was on par $(11.33 \mathrm{~cm}$ and $5.13 \mathrm{~cm} \mathrm{cob}$ length and cob girth respectively) with $\mathrm{T}_{4}$ (150: 60: $40 \mathrm{~kg}$ NPK ha ${ }^{-1} ; 1 / 2 \mathrm{~N}+1 / 2 \mathrm{~K}$ basal; $1 / 2$ $\mathrm{N}+1 / 2 \mathrm{~K}$ at $25 \mathrm{DAS})$. Significantly higher cob weight with husk (84.22 $\mathrm{g} \mathrm{plant}^{-1}$ ) was recorded by the treatment $\mathrm{T}_{7}$ and it was followed by $\mathrm{T}_{4}$ with a cob weight of $79.58 \mathrm{~g}$ plant $^{-1}$ (Table 2). 
Table.1 Effect of nutrient schedules on growth attributes of baby corn

\begin{tabular}{|c|c|c|c|c|c|c|c|c|c|c|}
\hline \multirow[t]{2}{*}{ Treatments } & \multicolumn{3}{|c|}{$\begin{array}{l}\text { Plant height } \\
\quad(\mathrm{cm})\end{array}$} & \multicolumn{3}{|c|}{$\begin{array}{l}\text { Number of leaves } \\
\left(\text { no. } \text { plant }^{-1}\right)\end{array}$} & \multicolumn{3}{|c|}{ Leaf area index } & \multirow{2}{*}{$\begin{array}{c}\text { Total dry } \\
\text { matter } \\
\left(\mathrm{kg} \mathrm{ha}^{-1}\right)\end{array}$} \\
\hline & $\begin{array}{c}15 \\
\mathrm{DAE}\end{array}$ & $\begin{array}{c}30 \\
\text { DAE }\end{array}$ & $\begin{array}{c}45 \\
\mathrm{DAE}\end{array}$ & $\begin{array}{c}15 \\
\text { DAE }\end{array}$ & $\begin{array}{c}30 \\
\mathrm{DAE}\end{array}$ & $\begin{array}{c}45 \\
\mathrm{DAE}\end{array}$ & $\begin{array}{c}15 \\
\text { DAE }\end{array}$ & $\begin{array}{c}30 \\
\mathrm{DAE}\end{array}$ & $\begin{array}{c}45 \\
\mathrm{DAE}\end{array}$ & \\
\hline $\begin{aligned} T_{1}: & 100: 40: 60 \mathrm{~kg} \mathrm{NPK} \mathrm{ha}^{-1} \\
& 1 / 2 \mathrm{~N}+1 / 2 \mathrm{~K} \text { basal } ; 1 / 2 \mathrm{~N}+1 / 2 \mathrm{~K} \text { at } 25 \mathrm{DAS}\end{aligned}$ & 49.20 & 108.85 & 159.06 & 5.05 & 7.99 & 11.55 & 0.25 & 1.95 & 3.72 & 18757.40 \\
\hline $\begin{aligned} \mathrm{T}_{2}: & 100: 40: 60 \mathrm{~kg} \mathrm{NPK} \mathrm{ha}^{-1} \\
& 1 / 2 \mathrm{~N}+1 / 2 \mathrm{~K} \text { basal } ; 1 / 2 \mathrm{~N}+1 / 2 \mathrm{~K} \text { at } 45 \text { DAS }\end{aligned}$ & 50.87 & 108.55 & 170.38 & 4.99 & 7.78 & 11.55 & 0.21 & 1.68 & 3.38 & 17631.48 \\
\hline $\begin{aligned} \mathrm{T}_{3}: & 100: 40: 60 \mathrm{~kg} \mathrm{NPK} \mathrm{ha}{ }^{-1} \\
& 1 / 2 \mathrm{~N}+1 / 2 \mathrm{~K} \text { basal } ; 1 / 4 \mathrm{~N}+1 / 4 \mathrm{~K} \text { at } 25 \text { DAS; } \\
& 1 / 4 \mathrm{~N}+1 / 4 \mathrm{~K} \text { at } 45 \mathrm{DAS}\end{aligned}$ & 43.96 & 107.83 & 165.80 & 4.61 & 7.67 & 11.72 & 0.24 & 1.87 & 3.52 & 17192.59 \\
\hline $\begin{aligned} \mathrm{T}_{4}: & 150: 60: 40 \mathrm{~kg} \mathrm{NPK} \mathrm{ha}^{-1} \\
& 1 / 2 \mathrm{~N}+1 / 2 \mathrm{~K} \text { basal } ; 1 / 2 \mathrm{~N}+1 / 2 \mathrm{~K} \text { at } 25 \text { DAS }\end{aligned}$ & 45.68 & 122.74 & 165.23 & 4.94 & 7.61 & 11.66 & 0.30 & 2.02 & 4.06 & 19913.06 \\
\hline $\begin{array}{ll}T_{5}: & 150: 60: 40 \mathrm{~kg} \mathrm{NPK} \mathrm{ha}^{-1} \\
& 1 / 2 \mathrm{~N}+1 / 2 \mathrm{~K} \text { basal } ; 1 / 2 \mathrm{~N}+1 / 2 \mathrm{~K} \text { at } 45 \mathrm{DAS}\end{array}$ & 51.47 & 114.14 & 170.40 & 5.27 & 8.33 & 11.50 & 0.26 & 1.97 & 3.52 & 18940.747 \\
\hline $\begin{array}{ll}\mathrm{T}_{6}: & 150: 60: 40 \mathrm{~kg} \mathrm{NPK} \mathrm{ha}{ }^{-1} \\
1 / 2 \mathrm{~N}+1 / 2 \mathrm{~K} \text { basal } ; 1 / 4 \mathrm{~N}+1 / 4 \mathrm{~K} \text { at } 25 \text { DAS } \\
1 / 4 \mathrm{~N}+1 / 4 \mathrm{~K} \text { at } 45 \mathrm{DAS}\end{array}$ & 47.88 & 108.31 & 166.91 & 4.94 & 7.66 & 11.77 & 0.28 & 1.99 & 3.67 & 19215.74 \\
\hline $\begin{aligned} \mathrm{T}_{7}: & 135: 65: 45 \mathrm{~kg} \mathrm{NPK} \mathrm{ha}^{-1} \\
& 1 / 2 \mathrm{~N}+1 / 2 \mathrm{~K} \text { basal } ; 1 / 2 \mathrm{~N}+1 / 2 \mathrm{~K} \text { at } 25 \text { DAS }\end{aligned}$ & 50.30 & 125.16 & 172.30 & 5.11 & 7.83 & 11.89 & 0.36 & 2.25 & 4.29 & 24203.70 \\
\hline $\begin{array}{ll}\text { T }_{8}: & 135: 65: 45 \mathrm{~kg} \mathrm{NPK} \mathrm{ha}^{-1} \\
& 1 / 2 \mathrm{~N}+1 / 2 \mathrm{~K} \text { basal } ; 1 / 2 \mathrm{~N}+1 / 2 \mathrm{~K} \text { at } 45 \mathrm{DAS}\end{array}$ & 45.54 & 112.56 & 166.73 & 5.17 & 8.28 & 11.28 & 0.34 & 1.98 & 3.91 & 9858.33 \\
\hline $\begin{array}{ll}T_{9}: & 135: 65: 45 \mathrm{~kg} \mathrm{NPK} \mathrm{ha}^{-1} \\
1 / 2 \mathrm{~N}+1 / 2 \mathrm{~K} \text { basal } ; 1 / 4 \mathrm{~N}+1 / 4 \mathrm{~K} \text { at } 25 \text { DAS; } \\
\\
1 / 4 \mathrm{~N}+1 / 4 \mathrm{~K} \text { at } 45 \text { DAS }\end{array}$ & 50.78 & 115.91 & 171.26 & 5.05 & 8.33 & 11.55 & 0.31 & 2.03 & 4.02 & 17459.25 \\
\hline $\mathbf{T}_{10}:$ Control & 43.68 & 96.52 & 146.68 & 4.99 & 7.33 & 10.72 & 0.14 & 1.42 & 2.29 & 13191.66 \\
\hline SE m $( \pm)$ & 2.83 & 3.54 & 3.74 & 0.11 & 0.28 & 0.18 & 00 & 0.03 & 0.05 & 436.23 \\
\hline CD (0.05) & NS & 10.519 & NS & NS & $\mathrm{NS}$ & 0.555 & 0.029 & 0.100 & 0.168 & 1296.186 \\
\hline
\end{tabular}

DAE: Days after emergence DAS: Days after sowing

Note: Farm yard manure @ $12.5 \mathrm{t} \mathrm{ha}^{-1}$ was applied uniformly to all the treatments, including control. The entire dose of phosphorus was applied as basal in treatments $T_{1}$ to $T_{9}$. 
Table.2 Effect of nutrient schedules on yield attributes and yields of baby corn

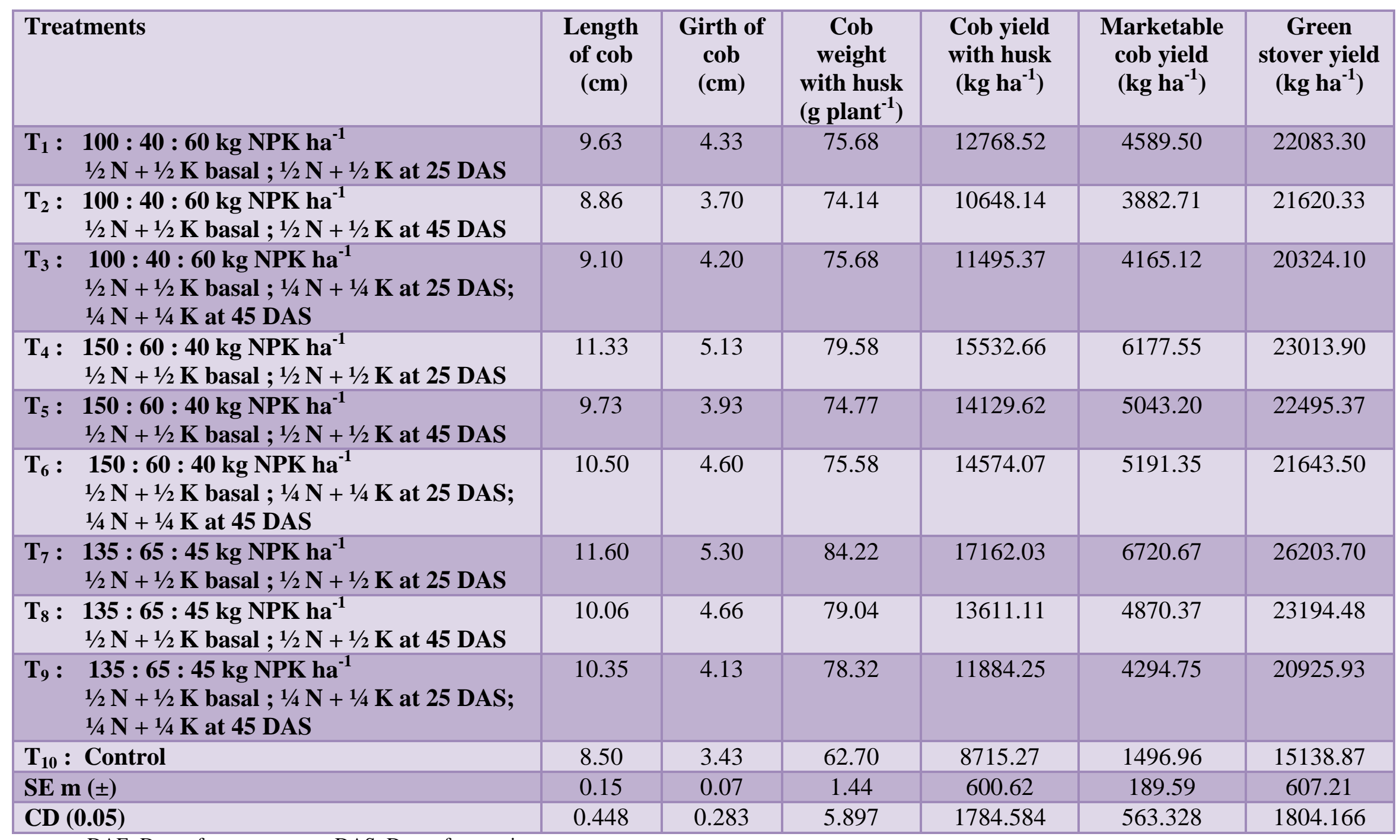

DAE: Days after emergence DAS: Days after sowing

Note: Farm yard manure @ $12.5 \mathrm{tha}^{-1}$ was applied uniformly to all the treatments, including control. The entire dose of phosphorus was applied as basal in treatments $T_{1}$ to $T_{9}$. 
Table.3 Effect of nutrient schedules on uptake of nitrogen, phosphorus and potassium, $\mathrm{kg} \mathrm{ha}^{-1}$

\begin{tabular}{|c|c|c|c|}
\hline \multirow[t]{2}{*}{ Treatments } & \multicolumn{3}{|c|}{ Nutrient uptake } \\
\hline & Nitrogen & Phosphorus & Potassium \\
\hline $\begin{array}{ll}T_{1}: & 100: 40: 60 \mathrm{~kg} \mathrm{NPK} \mathrm{ha} \\
& 1 / 2 \mathrm{~N}+1 / 2 \mathrm{~K} \text { basal } ; 1 / 2 \mathrm{~N}+1 / 2 \mathrm{~K} \text { at } 25 \\
\text { DAS }\end{array}$ & 249.43 & 38.41 & 244.99 \\
\hline $\begin{array}{ll}T_{2}: & 100: 40: 60 \mathrm{~kg} \mathrm{NPK} \mathrm{ha}^{-1} \\
& 1 / 2 \mathrm{~N}+1 / 2 \mathrm{~K} \text { basal } ; 1 / 2 \mathrm{~N}+1 / 2 \mathrm{~K} \text { at } 45 \\
\text { DAS } & \end{array}$ & 195.87 & 35.92 & 173.07 \\
\hline 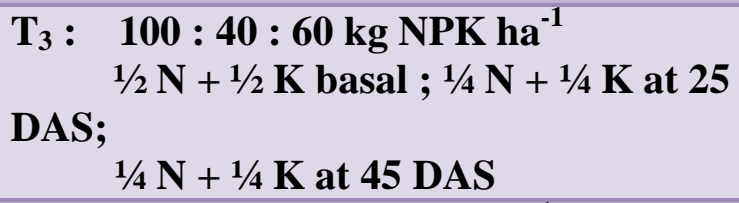 & 200.10 & 33.42 & 212.22 \\
\hline $\begin{array}{ll}\text { T }_{4}: & 150: 60: 40 \mathrm{~kg} \mathrm{NPK} \mathrm{ha}^{-1} \\
& 1 / 2 \mathrm{~N}+1 / 2 \mathrm{~K} \text { basal } ; 1 / 2 \mathrm{~N}+1 / 2 \mathrm{~K} \text { at } 25 \\
\text { DAS }\end{array}$ & 298.23 & 43.55 & 183.67 \\
\hline 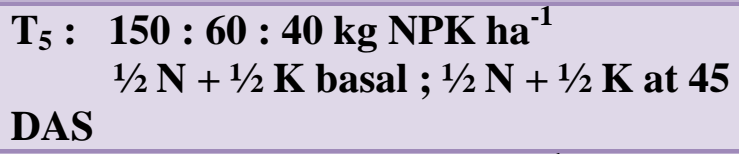 & 230.54 & 43.43 & 175.50 \\
\hline $\begin{array}{l}\text { T }_{6}: 150: 60: 40 \mathrm{~kg} \mathrm{NPK} \mathrm{ha}^{-1} \\
1 / 2 \mathrm{~N}+1 / 2 \mathrm{~K} \text { basal } ; 1 / 4 \mathrm{~N}+1 / 4 \mathrm{~K} \text { at } 25 \\
\text { DAS; } \\
1 / 4 \mathrm{~N}+1 / 4 \mathrm{~K} \text { at } 45 \text { DAS }\end{array}$ & 254.19 & 42.11 & 195.66 \\
\hline 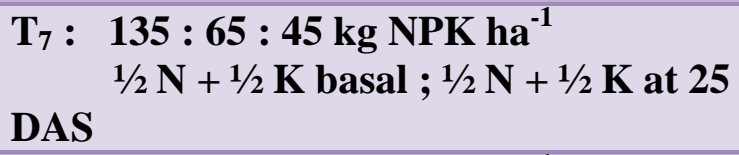 & 304.63 & 59.65 & 277.01 \\
\hline 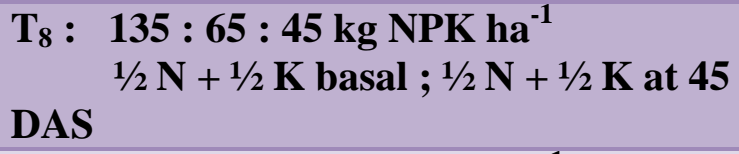 & 221.64 & 45.98 & 177.00 \\
\hline 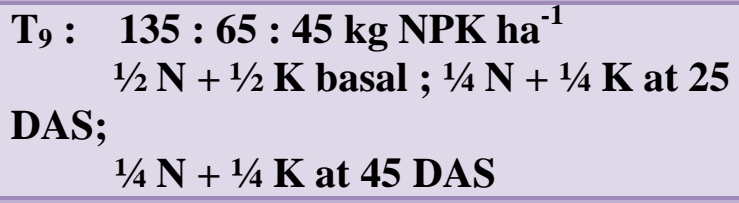 & 223.05 & 40.43 & 192.96 \\
\hline $\mathbf{T}_{10}:$ Control & 122.28 & 21.30 & 58.03 \\
\hline SE m $( \pm)$ & 10.47 & 1.11 & 13.37 \\
\hline CD (0.05) & 31.136 & 5.730 & 39.740 \\
\hline
\end{tabular}

DAS: Days after sowing

Note: Farm yard manure @ $12.5 \mathrm{t} \mathrm{ha}^{-1}$ was applied uniformly to all the treatments, including control. The entire dose of phosphorus was applied as basal in treatments $\mathrm{T}_{1}$ to $\mathrm{T}_{9}$. 
Table.4 Effect of nutrient schedules on gross income, net income and B: C ratio

\begin{tabular}{|c|c|c|c|}
\hline Treatments & $\begin{array}{c}\text { Gross } \\
\text { income }\end{array}$ & $\begin{array}{c}\text { Net } \\
\text { income }\end{array}$ & $\begin{array}{l}\text { B:C } \\
\text { ratio }\end{array}$ \\
\hline $\begin{array}{l}\text { T }_{1}: 100: 40: 60 \mathrm{~kg} \mathrm{NPK}^{-1} \mathrm{ha}^{-1} \\
1 / 2 \mathrm{~N}+1 / 2 \mathrm{~K} \text { basal } ; 1 / 2 \mathrm{~N}+1 / 2 \mathrm{~K} \text { at } 25 \\
\text { DAS }\end{array}$ & 183580 & 106606 & 2.39 \\
\hline $\begin{array}{l}T_{2}: 100: 40: 60 \mathrm{~kg} \mathrm{NPK} \mathrm{ha}^{-1} \\
\text { 1/2 N + 1/2 K basal } ; 1 / 2 \mathrm{~N}+1 / 2 \mathrm{~K} \text { at } 45 \\
\text { DAS }\end{array}$ & 155308 & 78334 & 2.02 \\
\hline $\begin{array}{l}\text { T }_{3}: \quad 100: 40: 60 \mathrm{~kg} \mathrm{NPK} \mathrm{ha}^{-1} \\
1 / 2 \mathrm{~N}+1 / 2 \mathrm{~K} \text { basal } ; 1 / 4 \mathrm{~N}+1 / 4 \mathrm{~K} \text { at } 25 \\
\text { DAS; } \\
1 / 4 \mathrm{~N}+1 / 4 \mathrm{~K} \text { at } 45 \mathrm{DAS}\end{array}$ & 166604 & 88366 & 2.13 \\
\hline $\begin{array}{l}\text { T }_{4}: 150: 60: 40 \mathrm{~kg} \mathrm{NPK} \mathrm{ha}^{-1} \\
\quad 1 / 2 \mathrm{~N}+1 / 2 \mathrm{~K} \text { basal } ; 1 / 2 \mathrm{~N}+1 / 2 \mathrm{~K} \text { at } 25 \\
\text { DAS }\end{array}$ & 247102 & 168617 & 3.15 \\
\hline $\begin{array}{l}T_{5}: 150: 60: 40 \mathrm{~kg} \mathrm{NPK} \mathrm{ha}^{-1} \\
\quad 1 / 2 \mathrm{~N}+1 / 2 \mathrm{~K} \text { basal } ; 1 / 2 \mathrm{~N}+1 / 2 \mathrm{~K} \text { at } 45 \\
\text { DAS }\end{array}$ & 201728 & 123243 & 2.57 \\
\hline 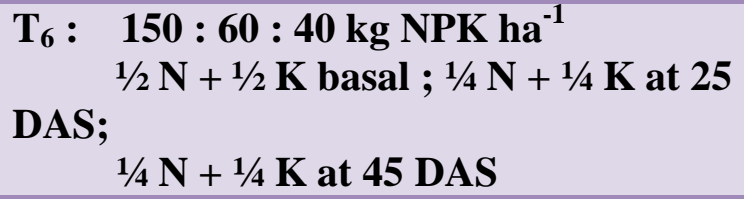 & 207654 & 126642 & 2.57 \\
\hline $\begin{array}{l}\text { T }_{7}: 135: 65: 45 \mathrm{~kg} \mathrm{NPK} \mathrm{ha}^{-1} \\
1 / 2 \mathrm{~N}+1 / 2 \mathrm{~K} \text { basal } ; 1 / 2 \mathrm{~N}+1 / 2 \mathrm{~K} \text { at } 25 \\
\text { DAS }\end{array}$ & 268827 & 190367 & 3.43 \\
\hline $\begin{array}{l}\text { T}_{8}: 135: 65: 45 \mathrm{~kg} \mathrm{NPK} \mathrm{ha}^{-1} \\
\quad 1 / 2 \mathrm{~N}+1 / 2 \mathrm{~K} \text { basal } ; 1 / 2 \mathrm{~N}+1 / 2 \mathrm{~K} \text { at } 45 \\
\text { DAS }\end{array}$ & 194814 & 116354 & 2.48 \\
\hline $\begin{array}{l}\text { T }_{9}: \quad 135: 65: 45 \mathrm{~kg} \mathrm{NPK} \mathrm{ha}^{-1} \\
1 / 2 \mathrm{~N}+1 / 2 \mathrm{~K} \text { basal } ; 1 / 4 \mathrm{~N}+1 / 4 \mathrm{~K} \text { at } 25 \\
\text { DAS; } \\
1 / 4 \mathrm{~N}+1 / 4 \mathrm{~K} \text { at } 45 \mathrm{DAS}\end{array}$ & 171790 & 91435 & 2.13 \\
\hline $\mathbf{T}_{10}:$ Control & 59878 & -850 & 0.98 \\
\hline SE m $( \pm)$ & 7583.67 & 7583.67 & 0.09 \\
\hline CD (0.05) & 22533.073 & 22533.073 & 0.285 \\
\hline
\end{tabular}

DAS: Days after sowing

Note: Farm yard manure @ $12.5 \mathrm{t} \mathrm{ha}^{-1}$ was applied uniformly to all the treatments, including control. The entire dose of phosphorus was applied as basal in treatments $\mathrm{T}_{1}$ to $\mathrm{T}$. 
The treatment $\mathrm{T}_{7}$ (135: 65: $45 \mathrm{~kg}$ NPK ha ${ }^{-1} ; 1 / 2$ $\mathrm{N}+1 / 2 \mathrm{~K}$ as basal; $1 / 2 \mathrm{~N}+1 / 2 \mathrm{~K}$ at $25 \mathrm{DAS}$ ) produced significantly larger cobs (in terms of both length and girth), higher cob yield with husk (17162.03 kg ha $\mathrm{kg}^{-1}$ ) and marketable cob yield $\left(6720.67 \mathrm{~kg} \mathrm{ha}^{-1}\right)$ and remained at par $\left(15532.66 \mathrm{~kg} \mathrm{ha}^{-1}\right.$ and $6177.55 \mathrm{~kg} \mathrm{ha}^{-1} \mathrm{cob}$ yield with husk marketable cob yield respectively) with $\mathrm{T}_{4}$ (150: 60: $40 \mathrm{~kg} \mathrm{NPK} \mathrm{ha}$ ; $1 \frac{1}{2} \mathrm{~N}+1 / 2 \mathrm{~K}$ as basal; $1 / 2 \mathrm{~N}+1 / 2 \mathrm{~K}$ at 25 DAS). Significantly higher green stover yield (26203.70 kg ha ${ }^{-1}$ ) was obtained in $\mathrm{T}_{7}$.

The results suggested the positive influence of nutrients in increasing the marketable cob yield. Increased level of NPK might have provided the crop with a balanced nutrient supply resulting in improved growth attributes such as plant height, leaf area index and dry matter production and consequently increased the yield attributes and yield of baby corn. Similar results have been reported by (Sobhana et al., (2012) and Kumar and Bohra (2014). Improvement in marketable cob yield could be attributed to the higher photosynthetic rates at $T_{7}$ and $T_{4}$ resulting from better light interception, light absorption and radiation use efficiency. This is in consonance with the findings of Madhavi et al. (1995) and Thavaprakash et al. (2005).

\section{Nutrient uptake}

Nutrient schedules had significant effect on nutrient uptake. Uptake of nitrogen, phosphorus and potassium was significantly higher in $\mathrm{T}_{7}$ (135: 65: $45 \mathrm{~kg}$ NPK ha ${ }^{-1} ; 1 / 2 \mathrm{~N}+$ $1 / 2 \mathrm{k}$ as basal; $1 / 2 \mathrm{~N}+1 / 2 \mathrm{~K}$ at $25 \mathrm{DAS}$ ). The treatment $\mathrm{T}_{7}$ was observed to record significantly higher plant height, leaf area index, marketable cob yield, green stover yield and consequently higher dry matter production. Nutrient uptake is the function of dry matter production and nutrient content. This is also in accordance with the findings of Fageria and Baligar (2005) who have stated that nutrient accumulation pattern in plant followed dry matter accumulation (Table 3 ).

\section{Economics}

The cost of inputs and produce vary widely, both temporally and spatially. Cost of cultivation was highest at $\mathrm{T}_{6}$ (150: $60: 40 \mathrm{~kg}$ NPK ha ${ }^{-1} ; 1 / 2 \mathrm{~N}+1 / 2 \mathrm{k}$ as basal; $1 / 4 \mathrm{~N}+1 / 4 \mathrm{~K}$ at 25 DAS and $1 / 4 \mathrm{~N}+1 / 4 \mathrm{~K}$ at $45 \mathrm{DAS}$ ). This might be due to the higher nutrient dose clubbed together with two top dressings. Cost of cultivation was least for control. However, the higher cost of cultivation in $\mathrm{T}_{6}$ was not compensated with an equally high gross income, net income and BCR.

Gross income ( $₹ 268827 \mathrm{ha}^{-1}$ ), net income (₹ $190367 \mathrm{ha}^{-1}$ ) and BCR (3.43) were significantly high for the treatment $\mathrm{T}_{7}$. It was on par with $\mathrm{T}_{4}$ which recorded a gross income of ₹ $247102 \mathrm{ha}^{-1}$, net income of ₹ $168617 \mathrm{ha}^{-}$ 1 and BCR of 3.15. The effect of the treatments $\mathrm{T}_{7}$ and $\mathrm{T}_{4}$ could be attributed to the significantly high marketable cob yield (Table 4).

In conclusion, growth attributes, yield attributes, yield, nutrient use efficiency and profitability of baby corn intercropped in coconut garden was observed to be superior with the application of FYM @ $12.5 \mathrm{t} \mathrm{ha}^{-1}+$ 135: 65: $45 \mathrm{~kg} \mathrm{NPK} \mathrm{ha}^{-1}(1 / 2 \mathrm{~N}+$ full $\mathrm{P}+\mathrm{K}$ as basal; $1 / 2 \mathrm{~N}+1 / 2 \mathrm{~K} @ 25 \mathrm{DAS})$.

\section{References}

Ahmad, M., Buksh, H.A., Ahmad, R. and Khan DG. 2012. Nutritional and physiological significance of potassium application in maize hybrid crop production. Pakistan J. Nutr. 11 (2): 187 $-202$.

Balakrishnan, K., Sundaran, K. M., Natarajarathinam, N. and Vijayraghavan, H. 1987. Note on the 
estimation of the leaf area in maize by non-destructive method. Madras Agric. J. 74 (3): 160-162

CPCRI [Central Plantation Crops Research Institute]. 2012, Research Highlights 2011-2012. Central Plantation Crops Research Institute, Kasaragod, p.15.

Fageria N.K., and Baligar, V.C. 2005. Enhancing nitrogen use efficiency in crop plants. Adv. Agron. 88: 97-185.

Jackson, M.L. 1973. Soil Chemical Analysis. Prentice Hall of India Pvt. Ltd., New Delhi.

Kumar, R, and Bohra, J.S. 2014. Effect of NPKS and Zn application on growth, yield, economics and quality of baby corn. Arch. Agron. Soil Sci. 60(1): 1193 - 1206.

Madhavi, B.L., Reddy, M.S. and Rao, P.C. 1995. Integrated nutrient management using poultry manures and fertilizers for maize. Indian J. Agron. 40:307- 310.

Mohan, S., Singh, M. and Kumar, R. 2015. Effect of nitrogen, phosphorus and zinc fertilization on yield and quality of kharif fodder - a review. Agric. Rev. 36(3): $218-226$

Muchow, R.C., and Davis, R. 1988. Effect of nitrogen supply on comparative productivity of maize and sorghum in semi -arid tropical environment: radiation interception and biomass accumulation. Field Crops Res. 18: 1730.

Muthukumar, V.B., Velayudham, K. and Thavaprakaash, N. 2005. Growth and yield of baby corn (Zea mays L.) as influenced by plant growth regulators and different time of nitrogen application. Res. J. Agric. Biol. Sci. 1(4):303-307.

Nagdeve, D.P., Bharti, Y.P. and Kumar, A. 2014. Efficacy of herbicides as plant growth regulator on productivity of maize with special aspect of baby corn. Int. J. Med. Sci. Clin. Invention 1(6): 316-327.

Pandey, A.K., Prakash, V., Mani, V.P. and Singh, R.D.. 2000. Effect of rate of nitrogen and time of application on yield and economics of baby corn (Zea mays L.). Indian J. Agron. 45(2): 338 343.

Panse, V.G. and Sukhatme, P.V. 1967. Statistical Methods for Agricultural Workers I.C.A.R., New Delhi.Sobhana V. K., Idnani, L. K., Singh, I., Dhar, S., 2012, Plant population and nutrient requirement for baby corn hybrids (Zea mays). Indian J. Agron. 57: 294 - 296.

Thavaprakaash, N., Velayudham, K. and Muthukumar, V.B. 2005. Study of crop geometry, intercropping systems and nutrient management practices on weed density and yield in baby corn based intercropping systems. Madras Agric. J. 92(7-9): 407-414.

Thavaprakash, N., and Velayudham, K. 2008. Light interception and productivity of baby corn as influenced by crop geometry, intercropping systems and INM practices. Asian J. Sci. Res. 1(1): 72-78.

\section{How to cite this article:}

Vinod Mavarkar, P. Shalini Pillai and Radhakrishnan, N.V. 2019. Nutrient Scheduling for Baby Corn (Zea mays L.) Intercropped in Coconut Garden. Int.J.Curr.Microbiol.App.Sci. 8(09): 581-589. doi: https://doi.org/10.20546/ijcmas.2019.809.070 